\title{
Penyuluhan kepada masyarakat tentang keefektifan obat hidroksikloroquin sebagai alternatif pencegahan dan pengobatan COVID-19
}

\author{
Dina Ahsana1, Muhammad Nadziri', Hendera ${ }^{1}$ \\ 1Program Studi S1 Farmasi, Fakultas Farmasi, Universitas Muhammadiyah Banjarmasin, Indonesia
}

\section{DOI: https://doi.org/10.29303/indra.v2i1.50}

\section{Article Info}

Received : 02-08-2020

Revised : 28-09-2020

Accepted: 11-11-2020

\begin{abstract}
COVID-19 infection is a disease with a very rapid spread and multiorgan failure can occur rapidly resulting in death in a short time. Many rumored treatments can ward off this infection, one of them is Hydroxychloroquine. The purpose of this community service activity is to provide correct information on the use of Hydroxychloroquine drugs in the prevention and treatment of COVID-19 and how to stop the spreading chain of infection to improve the degree of public health. This is a quantitative research with a Pre-Experimental method using One Group Pretest-Posttest Design and data collection instruments used are multiple choice question types. The results of 33 participant's complete data were analyzed using statistics with the Wilcoxon test with a $\mathrm{P}$-value of $0,000(\mathrm{P}<0.05)$. The results showed the participants got more clear the information about this Hydroxychloroquine before and after education, this shows that the use of the method has succeeded in increasing the knowledge and understanding of participants about "The Effectiveness of Hydroxychloroquine Drug as Alternative Prevention and Treatment of COVID-19".
\end{abstract}

Keywords: Chloroquine, Hydroxychloroquine, COVID-19, SARS-COV-2.

Citation: Hendera, Ahsana, D., \& Nadzir, P. (2020). Penyuluhan Kepada Masyarakat Tentang Keefektifan Obat Hidroksikloroquin Sebagai Alternatif Pencegahan Dan Pengobatan COVID-19. INDRA Jurnal Pengabdian kepada Masyarakat, 2(1), 1-7. doi: https://doi.org/10.29303/indra.v2i1.50

\section{Pendahuluan}

Infeksi COVID-19 menyebar dengan cepat dan telah banyak merenggut jiwa. Kasus pertama dilaporkan pada 18-29 Desember 2019 yaitu terdapat 5 pasien dirawat di rumah sakit dengan sindrom gangguan pernapasan akut dan satu diantaranya meninggal (L. L. Ren et al., 2020). 2 Januari 2020 sebanyak 41 pasien rawat inap di rumah sakit terinfeksi COVID-19, beberapa diantaranya mempunyai penyakit penyerta seperti diabetes, hipertensi, dan penyakit kardiovaskular (Huang et al., 2020). Hingga pada 22 Januari 2020 total 571 kasus coronavirus baru (COVID19) dilaporkan di 25 provinsi (kabupaten dan kota) di Cina dan 17 orang meninggal (W. Wang et al., 2020). Puncaknya pada 30 Januari 2020, dilaporkan 7734 kasus dikonfirmasikan di Cina dan 90 kasus infeksi sudah menyebar diberbagai negara lain (Bassetti et al., 2020). Sampai sekarang 4 juli 2020 secara global dari data WHO (2020) telah dilaporkan 10.922.324 terkonfirmasi COVID-19 pada 216 negara dan 523.011 diantaranya meninggal.

Di Indonesia berdasarkan data 4 juli 2020 dari Gugus Tugas Percepatan Penanganan COVID-19 (2020) telah melaporkan sebanyak 62.142 positif COVID-19, 28.219 diantaranya sembuh dan 3.089 meninggal. Terkhusus untuk Kalimantan Selatan terdapat 3.520 orang yang positif, 2.399 diantaranya masih dirawat, 923 sembuh dan 198 orang telah meninggal berdasarkan data Sekertariat Daerah Provinsi Kalimantan Selatan. Tingkat penyebaran dan kematian yang sangat tinggi 
dalam waktu singkat inilah yang menimbulkan banyak keresahan.

Coronavirus jenis ini sangatlah patogen karena tingkat penularanya dari hewan ke manusia dan sekarang bertransmisi dari manusia ke manusia (Tang et al., 2020) sehingga dapat menjadi ancaman besar bagi kesehatan masyarakat. Disisi lain banyak ilmuwan lain telah menunjukkan bukti bahwa virus ini tanpa disadari dapat dilepaskan selama pernafasan, berbicara, dan batuk dalam mikrodroplet $(>5 \mu \mathrm{m})$ maupun aerosol $(<5$ $\mu \mathrm{m})$ yang cukup kecil untuk tetap tinggal di udara dan menimbulkan risiko pajanan pada jarak di luar 1 hingga $2 \mathrm{~m}$ dari individu yang terinfeksi terutama diruang dengan ventilasi buruk, penyebaran inilah yang diduga penyebab infeksi asimtomatis (Morawska \& Milton, 2020). Disitus resmi WHO menyatakan memang ada kemungkinan transmisi secara airbon, namun bukti penelitian ini masih dikaji lebih lanjut (World Health Organization, 2020b).

Organisasi Kesehatan Dunia (WHO) pada 11 Februari 2020 secara resmi menamai penyakit ini dengan 'COVID-19' (Rothan \& Byrareddy, 2020). kemudian Komite Internasional Taksonomi Virus menamakan virus ini dengan "Severe Acute Respiratory Syndrome Coronavirus 2' (SARS-CoV-2) (L. Wang et al., 2020). Coronavirus (CoVs) milik keluarga Coronaviridae, subfamili Coronavirinae dan ordo Nidovirales (Pal et al., 2020). Terdiri asam ribonukleat $\left(s s R N A^{+}\right)$nonsegmentasi, beruntai tunggal, penampilan khasnya menyerupai mahkota (Corona dalam bahasa Latin berarti mahkota) (Thomas G. Ksiazek et al., 2020). Virus yang merupakan parasit obligat intraseluler ini hanya dapat memperbanyak diri dalam sel hidup (Kristianingrum et al., 2015).

Penderita penyakit COVID-19 memiliki prognosis yang baik, tetapi ada juga pasien yang kritis bahkan kematian. Sebagian besar dari pasien kritis dan mininggal tidak menunjukan manifestasi klinis pada tahap awal penyakit. Beberapa pasien hanya menunjukkan demam ringan, batuk, atau nyeri otot. Kondisi pasien tiba-tiba memburuk pada tahap lanjut penyakit atau dalam proses pemulihan. Acute Respiratory Distress Syndrome (ARDS) dan kegagalan multiorgan terjadi dengan cepat, yang mengakibatkan kematian dalam waktu singkat. Badai sitokin juga dianggap sebagai salah satu penyebab utama ARDS dan kegagalan banyak organ (Ye et al., 2020).

Perbanyakan coronavirus yang sangat cepat melalui beberapa siklus yaitu dimulai dengan penempelan virus ke sel host diperantarai oleh protein $S$ (Spike) yang berikatan kuat dengan reseptor (Angiotensin-Converting Enzyme 2) ACE-2 di permukaan sel host. ACE-2 dapat ditemukan pada beberapa bagian tubuh seperti pada mukosa oral, nasal, nasofaring, sumsum tulang belakang (Yuliana, 2020), sistem syaraf pusat, mata, paru-paru, hati, jantung, usus, (Gheblawi et al., 2020) dan ginjal (jumlah ekspresi ACE-2 100 kali lebih tinggi daripada di paru-paru) (L. Wang et al., 2020). Kemudian virus ini akan masuk ke dalam sel, genom RNA virus dilepaskan ke dalam sitoplasma lalu ditranslasikan menjadi dua poliprotein dan protein struktural, nantinya genom virus akan mulai untuk bereplikasi (Li et al., 2020) dilanjutkan dengan proses traskripsi dan translasi (Fehr \& Perlman, 2015). Partikel virus yang tumbuh dalam retikulum endoplasma dan sel badan golgi (Susilo et al., 2020) akan dilepaskan dari sel terinfeksi melalui eksositosis yang nantinya akan menyerang sel ginjal, sel hati, usus, limfosit $\mathrm{T}$, serta pernapasan saluran atas dan bawah (Sahin et al., 2020).

Salah satu obat yang banyak dilirik beberapa waktu lalu, bahkan sempat diborong diapotek oleh masyarakat yaitu Klorokuin dan turunannya Hidroksiklorokuin. Penggunaan obat antimalaria klorokuin sudah mulai dikurangi penggunaannya dikarenakan Plasmodium falciparum telah resisten terhadap obat tersebut. Hidroksiklorokuin digunakan pada penyakit autoimun tertentu, seperti lupus atau Rheumatoid arthritis (Roustit et al., 2020). Kedua obat ini termasuk golongan obat keras, yang ditandai logo lingkaran merah dengan huruf $\mathrm{K}$ berwarna hitam dan garis tepi lingkaran berwarna hitam, obat keras tidak dapat dibeli secara bebas, hanya dapat diperoleh dengan resep dokter dan aturan pemakaian juga harus sesuai anjuran dokter, karena memiliki efek samping yang berbahaya, salah satu efek sampingnya adalah gangguan jantung, dosis yang digunakan harus tepat, juga penggunaanya harus dalam pengawasan tenaga medis (Pratiwi et al., 2019). Dua obat ini memiliki aktivitas anti-inflamasi dan imunomodulator dengan mengatur produksi faktor nekrosis tumor (TNF), interferon, dan sitokin tertentu (Roustit et al., 2020). Aktivitas itulah yang diprediksi dapat menghambat virus.

Secara menyeluruh pada uji invitro pra klinis yang dilakukan oleh beberapa peneliti menunjukan baik Klorokuin maupun Hidroksiklorokuin memberikan hasil uji yang efektif dalam pengurangan dan penghambatan virus pada sel hewan uji (Shah et al., 2020). Hasil-hasil uji in vitro memperlihatkan hasil yang menjanjikan sehingga ada tuntutan yang luar biasa untuk menemukan pengobatan efektif dalam menghadapi keadaan darurat kesehatan global yang berkembang pesat ini, beberapa uji klinis pada pasien COVID-19 rawat inap yang diberikan Hidroksiklorokuin dilaksanakan mulai dari Desember 2019 hingga April 2020, dan setelah dianalisis ternyata ketujuh percobaan memiliki kelemahan metodologis dan hasil yang dipilih secara acak tidak sesuai standar sehingga perlu penyelidikan lebih lanjut. Sejauh ini, tidak ada bukti klinis yang cukup untuk mendukung 
penggunaan Klorokuin atau Hidroksiklorokuin secara rutin dalam pengobatan COVID-19 (Chowdhury et al., 2020). Terjadinya komplikasi penyakit jantung banyak dilaporkan pada pasien pengguna Klorokuin atau Hidroksiklorokuin yakni ditandai dengan adanya perpanjangan interval QT, Interval QT yang terlalu lama dapat menyebabkan aritmia yang berakibat pada kematian jantung secara mendadak (Chatre et al., 2018). Secara keseluruhan, peserta yang menggunakan Klorokuin atau Hidroksiklorokuin menunjukan efek buruk dibandingkan dengan plasebo (L. Ren, 2020).

Pada 15 Juni 2020 FDA telah mencabut izin penggunaan obat Hidroksiklorokuin karena menunjukkan tidak terdapat penurunan kematian atau mempercepat pemulihan pada pasien COVID-19 dan memiliki efek samping lebih besar pada jantung, rejimen dosis yang disarankan untuk Klorokuin dan Hidroksiklorokuin tidak efektif membunuh atau menghambat virus (U.S. Food and Drug Administration, 2020). Tepat pada 17 Juni 2020 WHO mengumumkan bahwa Hydroxychloroquine (HCQ) untuk pengobatan COVID-19 telah dihentikan, karena tidak menghasilkan pengurangan angka mortalitas pada pasien COVID-19 (World Health Organization, 2020).

Berdasarkan latar belakang tersebut, perlu dilakukannya edukasi untuk memberikan informasi yang benar kepada masyarakat tentang bahaya efek samping dari penggunaan bebas obat Hidroksiklorokuin dalam mencegah ataupun mengobati infeksi COVID-19 dan cara pemutusan rantai penyebaran infeksi sehingga dapat meningkatkan derajat kesehatan masyarakat.

\section{Metode}

Kegiatan penyuluhan edukasi tentang "Keefektifan Peran Obat Hidroksiklorokuin dalam COVID-19" dilaksanakan pada hari Sabtu, 11 Juli 2020 dimulai dari 11.00-13.00 WITA melalui media daring (ZOOM App). Sebanyak 52 orang dengan latar belakang beragam dari berbagai daerah dikalimantan menghadiri acara ini.

Kegiatan pengabdian pada masyarakat ini diawali dengan identifikasi masalah yang banyak dialami oleh masyarakat yaitu dilakukan pendekatan observasi terkait penyakit infeksi COVID-19 dan penggunaan obat untuk pencegahannya terutama Hidroksiklorokuin yang beberapa waktu lalu sempat menjadi perbincangan hangat. Dari identifikasi masalah tersebut maka dilakukan diskusi untuk meluruskan informasi penggunaan Hidroksiklorokuin dengan benar dan menyusun kegiatan penyuluhan dengan metode ceramah yang dilakukan secara interaktif menggunakan media Power Point, video dan Leaflet sehingga lebih menarik.
Jenis metode yang digunakan dalam penelitian kuantitatif ini menggunakan Pra-Eksperimen (PreEksperimental) yang merupakan penelitian sistematis untuk menguji hipotesis hubungan sebab-akibat. Desain yang digunakan dalam penelitian ini adalah Desain Satu Kelompok Pretes-Postest (One Group Pretest-Posttest). Evaluasi yang dilakukan dalam kegiatan penyuluhan ini dengan cara sebelum pemaparan materi oleh narasumber partisipan diberi soal Pre-test dan dilanjutkan pada akhir acara partisipan diberikan Posttest dengan soal yang sama bertujuan untuk mengetahui kemampuan pemahaman partisipan akan materi yang disampaikan.

Materi yang disampaikan dalam penyuluhan yaitu tentang bahayanya penyebaran dan infeksi COVID-19, pengenalan obat keras Klorokuin dan Hidroksiklorokuin, penjelasan tentang efek samping buruk yang ditimbulkan dari penggunaan tidak tepat dan pemaparan hasil studi penelitian obat Klorokuin dan Hidroksiklorokuin pada pasien COVID-19. Kemudian dijelaskan pula mengenai tata cara pencegahan infeksi COVID-19 dengan benar.

Dalam proses monitoring dan evaluasi dilihat dari bagaimana respon peserta selama kegiatan berlangsung, mulai dari keaktifan peserta saat bertanya dan menjawab pertanyaan. Selain itu peserta juga diberi questioner di awal dan akhir pertemuan sebagai bentuk evaluasi untuk mengetahui tingkat kepahaman peserta pada materi yang telah disampaikan.

\section{Hasil dan Pembahasan}

Kegiatan penyuluhan yang bertema "Keefektifan Obat Hidroksiklorokuin sebagai alternatif pencegahan dan pengobatan COVID-19" telah dilakukan oleh dosen dan mahasiswa pada mata kuliah KIE dari program studi S1 Farmasi Universitas Muhammadiyah Banjarmasin. Penyuluhan ini dilakukan dalam rangka memberikan informasi yang benar kepada masyarakat terkait penggunaan dan efek samping buruk dari pemakaian tidak tepat. Pelaksanaan kegiatan ini diharapkan dapat memutus rantai penyebaran infeksi COVID-19 sehingga meningkatkan derajat kesehatan masyarakat.

Kegiatan ini dilaksanakan tepat pada hari Sabtu, 11 Juli 2020 menggunakan media daring melalui aplikasi ZOOM. Kegiatan ini dimulai dari jam 11.00-13.00 WITA. Target partisipan yang mengikuti kegiatan ini awalnya hanya diperkirakan 20 orang, namun ternyata dapat dihadiri sebanyak 52 orang dengan latar belakang bermacam-macam mulai dari masyarakat umum, mahasiswa hingga pelajar dari berbagai daerah di Kalimantan seperti Banjarmasin, Martapura, Kandangan, Barabai, Batulicin, Tanah Bumbu dan Kuala Kapuas. 




Gambar 1. Partisipan Kegiatan Penyuluhan

Kegiatan ini sejalan dengan salah satu program Ikatan Apoteker Indonesia (IAI) yaitu mencerdaskan masyarakat dalam penggunaan obat yang baik dan benar sehingga meningkatkan tarap hidup masyarakat yang sehat. Juga sebanding dengan program pemerintah Gema Cermat yang bertujuan untuk mewujudkan kepedulian, kesadaran, pemahaman masyarakat dalam menggunakan obat rasional dan aman.

Pelaksanaanya dimulai dengan mengisi daftar hadir dan pemberian soal Pre-test kepada peserta sebelum pemaparan materi untuk mengukur pengetahuan paserta terhadap tema kegiatan penyuluhan ini kemudian dilanjutkan pemaparan topik oleh dua orang pemateri. Pemateri pertama menjelaskan tentang bahaya infeksi dan penyebaran COVID-19 (SARS-COV-2), pengenalan obat Klorokuin dan Hidroksiklorokuin yang dianggap efektif menghambat dan mengobati infeksi COVID-19, menjabarkan efek samping buruk dari penggunaan Klorokuin dan Hidroksiklorokuin yang tidak tepat, memaparkan hasil penelitian uji pra-klinis, uji klinis dan beberapa organisasi kesehatan dunia tentang penggunaan obat Hidroksiklorokuin yang tidak efektif digunakan pasien terinfeksi COVID-19. Dan pemateri kedua memperagakan sekaligus menjelaskan tentang tata cara pencegahan infeksi COVID-19 dengan benar yang dapat dilakukan oleh semua orang seperti penggunaan masker, cara cuci tangan, dan Social Physical Distancing. Dalam pemaparan materi juga diselangi video agar lebih menarik dan mudah dipahami

Para peserta sangat antusias mengikuti acara ini, dibuktikan dengan kehadiran mereka tepat waktu. Antusiasme juga terlihat dalam mendengarkan penjelasan dari pemateri dan banyaknya pertanyaan yang dilontarkan saat sesi tanya jawab terkait materi yang disampaikan. Beberapa pertanyaan yang diajukan salah satunya yaitu "apa yang akan terjadi bila kita sudah tidak melakukan tindakan pencegahan penularan COVID-19 sebelum vaksin dan obatnya ditemukan?"

Setelah sesi tanya jawab selesai, pemateri memberikan Post-test untuk mengukur tingkat penerimaan dan pemahaman peserta selama mengikuti kegiatan ini, disisi lain dapat juga digunakan untuk mengetahui keberhasilan dan evaluasi kegiatan agar mendapat hasil maksimal.

Adapun pertanyaan yang dikeluarkan pada Pretest dan Post-test ini berisi tentang pengetahuan akan penggunaan Hidroksiklorokuin dan pencegahan COVID-19, seperti: obat Hidroksiklorokuin adalah obat yang tepat digunakan sebagai; efek samping yang ditimbulkan akibat penggunaan obat Hidroksiklorokuin jangka panjang yang benar, kecuali; Berdasarkan data klinis yang diperoleh obat Hidroksiklorokuin /Klorokuin, Oxford University dan WHO mengkalim bahwa obat Hidroksiklorokuin dapat digunakan sebagai alternatif pencegahan dan penyembuhan infeksi, benarkah pernyataan tersebut; infeksi COVID-19 adalah virus yang paling banyak menyerang sistem; Contoh pencegahan COVID-19 tanpa obat-obatan, kecuali. Beberapa pertanyaan yang diajukan terkesan terbuka untuk mempermudah evaluasi pengetahuan dan pemahaman dari responden, walaupun tetap diberikan pilihan jawaban agar mempermudah peserta untuk menjawab.

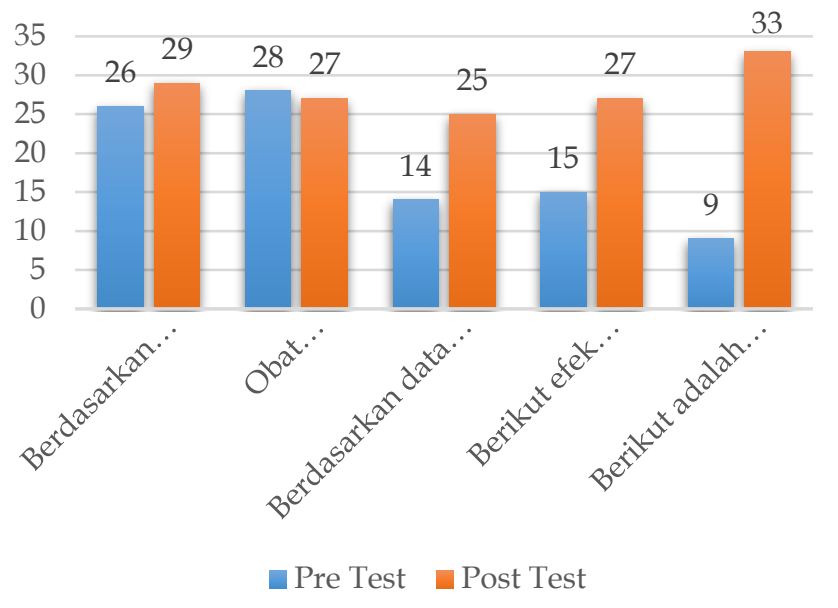

Gambar 2. Hasil Jawaban Benar dari Pre-test dan Post-test 33 Partisipan Terdata.

Dari gambar diagram 2 menunjukan bahwa secara umum terjadi peningkatan kemampuan partisipan dalam menjawab soal-soal dengan benar yang mengindikasikan terjadi peningkatan pemahaman partisipan akan topik materi yang disampaikan. Walaupun pada soal kedua menunjukan penurunan nilai dari Pre-test ke Post-test, hal tersebut mungkin dikarenakan adanya masalah pada jaringan internet yang mengganggu penyampaian informasi dalam sistem daring.

Hasil Pre-test menunjukan angka rata-rata jawaban benar dari 33 partisipan sebesar 62,24. Angka tersebut menunjukan nilai yang relatif cukup baik untuk pemahaman peserta sebelum menerima materi karena angka rata-rata tersebut melebihi 50, jika nilai rata-rata 
yang diperoleh kurang dari 50 maka dapat dikatakan bahwa peserta masih belum mendapatkan informasi yang tepat.

Berdasarkan hasil Post-test yang diberikan setelah kegiatan selesai dilaksanakan, diperoleh data yang menunjukkan angka rata-rata jawaban benar dari 33 partisipan sebesar 82,42 dan terjadi peningkatan nilai rata-rata 21,21. Dimana angka tersebut menunjukkan peningkatan yang signifikan dan mengindikasikan adanya peningkatan pengetahuan partisipan terkait penggunaan obat Hidroksiklorokuin yang tepat dan efek samping buruk yang ditimbulkan bila penggunaanya tidak sesuai, juga cara pengendalian infeksi COVID-19 dengan benar serta pencegahannya.

Selanjutnya nilai Pre-test dan Post-test dianalisis menggunakan uji normalitas Shapiro-Wilk untuk melihat distribusi data. Data uji normalitas Shapiro Wilk diketahui bahwa nilai Pre-test dan Post-test terdistribusi secara tidak normal (P-value $<0,005$ ) yaitu 0,002 untuk Pvalue Pre-test dan 0,000 untuk P-value Post-test.

Tabel 1. Hasil Uji Normalitas Pre-test dan

$$
\text { Post-test }
$$

\begin{tabular}{|c|c|c|c|c|c|c|}
\hline \multicolumn{7}{|c|}{ Tests of Normality } \\
\hline & \multicolumn{3}{|c|}{$\begin{array}{l}\text { Kolmogorov- } \\
\text { Smirnova }\end{array}$} & \multicolumn{3}{|c|}{ Shapiro-Wilk } \\
\hline & $\begin{array}{l}\text { Stat } \\
\text { istic }\end{array}$ & $\mathrm{df}$ & Sig. & $\begin{array}{l}\text { Stat } \\
\text { istic }\end{array}$ & $\mathrm{df}$ & Sig. \\
\hline $\begin{array}{l}\text { Pre } \\
\text { Test }\end{array}$ & .214 & 33 & .001 & .882 & 33 & .002 \\
\hline $\begin{array}{l}\text { Post } \\
\text { Test }\end{array}$ & .352 & 33 & .000 & .710 & 33 & .000 \\
\hline
\end{tabular}

a. Lilliefors Significance Correction

Selanjutnya, data nilai Pre-test dan Post-test dianalisis dengan metode uji non-parametrik, salah satu metodenya yaitu menggunakan uji Wilcoxon untuk mengetahui ada atau tidaknya perbedaan rata-rata dua sampel yang saling berpasangan. Hasil uji Wilcoxon ditampilkan dalam data berikut:

Tabel 2. Hasil Uji Wilcoxon Test Statistic

\begin{tabular}{ll}
\hline & Post Test - Pra Test \\
\hline $\mathrm{Z}$ & $-3.888^{\mathrm{b}}$ \\
Asymp. Sig. (2-tailed) & .000 \\
\hline
\end{tabular}

a. Wilcoxon Signed Ranks Test

b. Based on negative ranks.

Hasil analisis dengan uji Wilcoxon menunjukan adanya perbedaan rerata yang bermakna secara statistik antara nilai pre-test dan post-test dengan P-value 0,000 $(\mathrm{P}<0,05)$. Hasil tersebut menunjukan adanya perubahan pengetahuan dan pemahaman sebelum dan sesudah penyuluhan edukasi. Berdasarkan data hasil analisis bahwa penggunaan metode edukasi telah berhasil meningkatkan pengetahuan tentang "Keefektifan Obat Hidroksikloroquin Sebagai Alternatif Pencegahan dan Pengobatan COVID-19".

\section{Simpulan}

Telah dilaksanakan kegiatan pengabdian masyarakat dengan topik "Keefektifan Peran Obat Hidroksikloroquin dalam COVID-19" yang dilaksanakan pada hari sabtu, 11 Juli 2020 menggunakan media daring aplikasi ZOOM dengan partisipan sebanyak 52 orang. Kegiatan berjalan lancar sesuai rencana dan terlaksana dengan baik hal ini terlihat dari antusiasme partisipan saat sesi tanya jawab. Disisi lain, hasil post-tes dengan peningkatan rata-rata 21,21 dan nilai P-value $<0,05$ memperlihatkan nilai yang cukup bagus, artinya terjadi peningkatan pengetahuan partisipan akan informasi penggunaan obat hidroksikloroquin yang tepat, efek samping buruk yang ditimbukan bila penggunaanya tidak sesuai dan cara pengendalian infeksi COVID-19 dengan benar.

\section{Ucapan Terima Kasih}

Terima kasih kami ucapkan sebesar-besarnya kepada Dekan Fakultas Farmasi Universitas Muhammadiyah Banjarmasin yang telah memberikan izin kepada kami untuk melaksanakan kegiatan pengabdian masyarakat ini sehingga dapat berjalan dengan lancar sesuai dengan harapan.

\section{Daftar Pustaka}

Bassetti, M., Vena, A., \& Giacobbe, D. R. (2020). The novel Chinese coronavirus (2019-nCoV) infections: Challenges for fighting the storm. European Journal of Clinical Investigation, 50(3), 1-4. https://doi.org/10.1111/eci.13209

Chatre, C., Roubille, F., Vernhet, H., Jorgensen, C., \& Pers, Y. M. (2018). Cardiac Complications Attributed to Chloroquine and Hydroxychloroquine: A Systematic Review of the Literature. Drug Safety, 41(10), 919-931. https://doi.org/10.1007/s40264-018-0689-4

Chowdhury, M. S., Rathod, J., \& Gernsheimer, J. (2020). A Rapid Systematic Review of Clinical Trials Utilizing Chloroquine and Hydroxychloroquine as a Treatment for COVID-19. Academic Emergency Medicine. https://doi.org/10.1111/acem.14005

Fehr, A. R., \& Perlman, S. (2015). Coronaviruses: An Overview of Their Replication and Pathogenesis Anthony. Coronaviruses: Methods and Protocols, 1282(1), 1-282. https://doi.org/10.1007/978-14939-2438-7

Gheblawi, M., Wang, K., Viveiros, A., Nguyen, Q., Zhong, J. C., Turner, A. J., Raizada, M. K., Grant, 
M. B., \& Oudit, G. Y. (2020). AngiotensinConverting Enzyme 2: SARS-CoV-2 Receptor and Regulator of the Renin-Angiotensin System. Circulation Research, 1456-1474. https://doi.org/10.1161/CIRCRESAHA.120.3170 15

Gugus Tugas Percepatan Penanganan COVID-19. (2020). Peta Sebaran. https://covid19.go.id/

Huang, C., Wang, Y., Li, X., Ren, L., Zhao, J., Hu, Y., Zhang, L., Fan, G., Xu, J., Gu, X., Cheng, Z., Yu, T., Xia, J., Wei, Y., Wu, W., Xie, X., Yin, W., Li, H., Liu, M., ... Cao, B. (2020). Clinical features of patients infected with 2019 novel coronavirus in Wuhan, China. The Lancet, 395(10223), 497-506. https://doi.org/10.1016/S0140-6736(20)30183-5

Kristianingrum, Y. P., Tabbu, C. R., Sutrisno, B., Widyarini, S., Kurniasih, Untari, T., \& Kusumawati, A. (2015). "Deteksi Bovine Herpesvirus-1 Secara Immunohistokimia pada Membran Korioallantois Telur Ayam Berembrio (IMMUNOHISTOCHEMISTRY DETECTION OF BOVINE HERPESVIRUS-1 IN CORIOALLANTOIC MEMBRANE OF CHICKEN EMBRYONATED EGG)." Jurnal Veteriner, 16(4), 483-488.

https://doi.org/10.19087/jveteriner.2015.16.4.483

Li, X., Geng, M., Peng, Y., Meng, L., \& Lu, S. (2020). Molecular immune pathogenesis and diagnosis of COVID-19. Journal of Pharmaceutical Analysis, 10(2), 102-108.

https://doi.org/10.1016/j.jpha.2020.03.001

Morawska, L., \& Milton, D. K. (2020). It is Time to Address Airborne Transmission of COVID-19. 1-23. https://doi.org/https://doi.org/10.1093/cid/cia a939

Pal, M., Berhanu, G., Desalegn, C., \& Kandi, V. (2020). Severe Acute Respiratory Syndrome Coronavirus2 (SARS-CoV-2): An Update. Cureus, 2(3). https://doi.org/10.7759/cureus.7423

Pratiwi, B., Yuniar, C. T., R, I. B. M., \& Padmasawitri, T. I. A. (2019). Info Penting Pengobatan Covid-19. 1-4.

Ren, L. (2020). Assessment of Hydroxychloroquine and Chloroquine Safety Profiles A Systematic Review and Meta-Analysis. Medrxiv. https://doi.org/10.1101/2020.05.02.20088872

Ren, L. L., Wang, Y. M., Wu, Z. Q., Xiang, Z. C., Guo, L., Xu, T., Jiang, Y. Z., Xiong, Y., Li, Y. J., Li, X. W., Li, H., Fan, G. H., Gu, X. Y., Xiao, Y., Gao, H., Xu, J. Y., Yang, F., Wang, X. M., Wu, C., ... Wang, J. W. (2020). Identification of a novel coronavirus causing severe pneumonia in human: a descriptive study. Chinese Medical Journal, 133(9), 1015-1024. https://doi.org/10.1097/CM9.0000000000000722

Rothan, H. A., \& Byrareddy, S. N. (2020). The epidemeology and pathogensis of coronavirus (Covid-19) outbreak. Journal of Autoimmunity, 109(January), 1-4.

Roustit, M., Guilhaumou, R., Molimard, M., Drici, M.-D., Laporte, S., \& Montastruc, J.-L. (2020). Chloroquine and hydroxychloroquine in the management of COVID-19: Much kerfuffle but little evidence. Therapies, $1-8$. https://doi.org/10.1016/j.therap.2020.05.010

Sahin, A. R., Erdogan, A., Agaoglu, P. M., Dineri, Y., Cakirci, A. Y., Senel, M. E., Okyay, R. A., \& Tasdogan, A. M. (2020). 2019 Novel Coronavirus (COVID-19) Outbreak: A Review of the Current Literature. Eurasian Journal of Medicine and Oncology, 4(1), 1-7. https://doi.org/10.14744/ ejmo.2020.12220

Shah, S., Das, S., Jain, A., Misra, D. P., \& Negi, V. S. (2020). A systematic review of the prophylactic role of chloroquine and hydroxychloroquine in coronavirus disease-19 (COVID-19). International Journal of Rheumatic Diseases, 23(5), 613-619. https://doi.org/10.1111/1756-185X.13842

Susilo, A., Rumende, C. M., Pitoyo, C. W., Santoso, W. D., Yulianti, M., Herikurniawan, H., Sinto, R., Singh, G., Nainggolan, L., Nelwan, E. J., Chen, L. K., Widhani, A., Wijaya, E., Wicaksana, B., Maksum, M., Annisa, F., Jasirwan, C. O. M., \& Yunihastuti, E. (2020). Coronavirus Disease 2019: Tinjauan Literatur Terkini. Jurnal Penyakit Dalam Indonesia, 7(1), 45. https://doi.org/10.7454/jpdi.v7i1.415

Tang, D., Comish, P., \& Kang, R. (2020). The hallmarks of COVID-19 disease. PLoS Pathogens, 16(5), 1-24. https://doi.org/10.1371/journal.ppat.1008536

Thomas G. Ksiazek, Dean Erdman, D. P. H., Cynthia S. Goldsmith, M. S., Sherif R. Zaki, M. D. P. D., Teresa Peret, P. D., Shannon Emery, B. S., Suxiang Tong, P. D., Carlo Urbani, M. D., James A. Comer, P. D. M. P. H., Wilina Lim, M. D., Pierre E. Rollin, M. D., Scott F. Dowell, M. D. M. P. H., Ai-Ee Ling, M. D., Charles D. Humphrey, P. D., Wun-Ju Shieh, M.D., P. D., Jeannette Guarner, M. D., Christopher D. Paddock, M.D., M. P. H. T. M., Paul Rota, P. D., Barry Fields, P. D., ... Groupt, and the S. W. (2020). A Novel Coronavirus Associated with Severe Acute Respiratory Syndrome Thomas. The New England Journal of Medicine, 348(20), 1953-1966. https://doi.org/10.1093/jtm/taaa008 
U.S. Food and Drug Administration. (2020). Coronavirus (COVID-19) Update: FDA Revokes Emergency Use Authorization for Chloroquine and Hydroxychloroquine. https://www.fda.gov/newsevents/press-announcements/coronavirus-covid19-update-fda-revokes-emergency-useauthorization-chloroquine-and

Wang, L., Wang, Y., Ye, D., \& Liu, Q. (2020). Review of the 2019 novel coronavirus (SARS-CoV-2) based on current evidence. International Journal of Antimicrobial Agents, 55(January). https://doi.org/https://doi.org/10.1016/j.ijanti micag.2020.105948

Wang, W., Tang, J., \& Wei, F. (2020). Updated understanding of the outbreak of 2019 novel coronavirus (2019-nCoV) in Wuhan, China. Journal of Medical Virology, 92(4), 441-447. https://doi.org/10.1002/jmv.25689

WHO. (2020). WHO Coronavirus Disease (COVID-19) Dashboard. https://covid19.who.int/

World Health Organization. (2020a). "Solidarity" clinical trial for COVID-19 treatments. https://www.who.int/emergencies/diseases/no vel-coronavirus-2019/global-research-on-novelcoronavirus-2019-ncov/solidarity-clinical-trialfor-covid-19-treatments

World Health Organization. (2020b). Transmission of SARS-CoV-2: implications for infection prevention precautions. Scientific Brief. https://www.who.int/newsroom/commentaries/detail/transmission-of-sarscov-2-implications-for-infection-preventionprecautions

Ye, Q., Wang, B., \& Mao, J. (2020). The pathogenesis and treatment of the 'Cytokine Storm"' in COVID-19.' Journal of Infection, 80(6), 607-613. https://doi.org/10.1016/j.jinf.2020.03.037

Yuliana. (2020). Corona virus diseases (Covid -19); Sebuah tinjauan literatur. Wellness and Healthy Magazine, 2(1), 187-192. https://wellness.journalpress.id/wellness/article /view/v1i218wh 